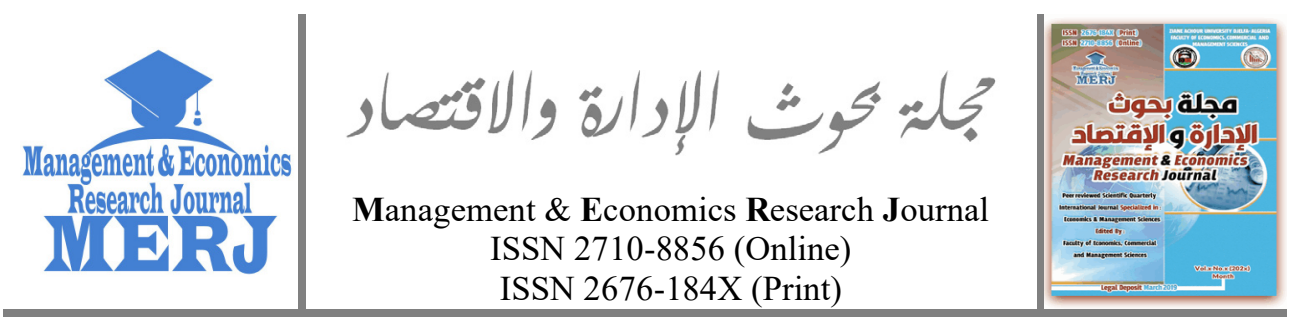

Vol. 3 No. 1 (2021), pp. 25-43

do) https://doi.org/10.48100/merj.2021.148

Check for updates

\title{
Long-Run Nexus of Tourism and Economic Growth in Sri Lanka: Empirical Evidence Using Cointegration Analysis
}

\author{
Nisantha Kurukulasooriya ${ }^{1}$, Erandathie Lelwala ${ }^{2}$ \\ ${ }^{1}$ Department of Economics, University of Ruhuna, Matara (Sri Lanka) \\ $\bowtie$ nisantha@econ.ruh.ac.lk \\ ${ }^{2}$ Department of Economics, University of Ruhuna, Matara (Sri Lanka) \\ $\triangle$ elwala@econ.ruh.ac.lk
}

Received: 29-01-2021

Accepted: 14-03-2021

Published online: 15-03-2021

\section{How to Cite:}

Nisantha, K., \& Erandathie, L. (2021). Long-Run Nexus of Tourism and Economic Growth in Sri Lanka: Empirical Evidence Using Cointegration Analysis. Management \& Economics Research Journal, 3(1), 25-43. https://doi.org/10.48100/merj.2021.148

\begin{abstract}
:
This study investigates the association between economic growth and tourism in Sri Lanka using cointegration analysis from 1980 to 2019. The research was performed using the Augmented Dickey-Fuller test, Phillips-Perron test, Engle-Granger cointegration, and Granger causality tests. The results revealed a long-run equilibrium relationship among variables, while a disequilibrium exists in the short run. The estimated error correction term is theoretically acceptable and found approximately 5 per cent yearly correction of its disequilibrium in the short run. The Granger causality test presented a long-run unidirectional causality from tourism to economic growth. Thus, findings confirm the tourism-led growth hypothesis in Sri Lanka's tourism and development spectrum. Therefore, tourism has a
\end{abstract}

• Corresponding author: Department of Economics, University of Ruhuna, Matara (Sri Lanka).

[ $\square$ nisantha@econ.ruh.ac.lk]

(C2021 the Author(s). This is an open-access article distributed under the terms of (CC BY-NC 4.0) which permits use, distribution and reproduction in any medium, provided the original work is properly cited and is not used for commercial purposes.

Faculty of Economics, Commercial \& Management

Sciences, Ziane Achour University of Djelfa, BP 3117, Djelfa - Algeria 
significant positive impact on economic activities in the long run. Findings further emphasise that the benefits of economic development must be transferred to the further development of tourism to maintain a bilateral causality which is an important concept in this regard. It provides the rationale for further developing productive policy strategies to attract more tourists to the country and upsurge visitor expenditures during their stay in Sri Lanka since Sri Lanka has significantly developed its accommodation capacities. Findings further reveal that the tourism sector must be developed parallel to economic development to boost growth through tourism. Therefore, all sectors, the government, private bodies, and voluntary organisations must become active partners in this endeavour. Policy implications need to focus on every aspect of enhancing tourism as a growth engine.

Keywords: Tourism, Economic Growth, Empirical Evidence, Sri Lanka. JEL Codes: C1, O47, Z32.

\section{Introduction}

The travel and tourism industry is one of the largest and fastestgrowing sectors of the global economy and is one of the crucial components of many national economies. Many developing countries have a significant interrelationship between tourism and economic growth (Tse, 2001). While tourism is a leisure and pleasure market, it also performs as an economic activity that develops according to economic forces. According to Wanhill (1994), tourism is a demand-led industry whose influence pervades many sectors of the economy. Tourism may be considered an export and import industry according to the economic theory of trade. It involves different types of organisations and individuals in their business activities. Therefore, one can argue that tourism contributes to the economic development of a destination country in its business form. According to the extant literature from developed and developing countries, the tourism industry and economic growth are somewhat interrelated (Chou, 2013; Du et al., 2016; Bianchi \& Man, 2020). Therefore, tourism is also considered an important sector of small economies in terms of economic growth. Therefore, Sri Lanka, as a small developing economy, an island, and a famous tourism destination in South Asia, must focus its policy agenda towards enhancing tourism-related activities in terms of the country's economic growth.

Sri Lanka's tourism sector evidenced smooth and significant growth from 1978 to 1982. Afterwards, this smooth growth of the tourism sector has interrupted due to uncontrollable interventions such as the ethnic war that prevailed over three decades, the tsunami in 2004, many terrorist 
attacks, including the Easter Sunday Attack in 2019, and the COVID-19 pandemic which has completely collapsed Sri Lanka's tourism industry. Accordingly, it has observed frequent irregular swings in foreign tourist arrivals due to these disturbances. Therefore, from 1982 to today, the tourism sector in Sri Lanka has not shown a smooth growth process. The highest arrivals in the history of Sri Lanka tourism were reported in 2018, which was reported in the post-war period and amounted to 253,169 heads. This resulted from the end of the civil war that prevailed for 30 years.

The tourism sector in Sri Lanka has shown its proven ability to generate income and employment in both formal and informal sectors. According to SLTAD (Sri Lanka Tourism Development Authority) (2019), the direct employment generation of tourism has amounted to 173,592 employees, while its indirect employment creation approximated 229,015 heads. It is the third foreign exchange earner to Sri Lanka, and tourism contributes to the Sri Lanka economy by 4.3 per cent of the GDP. The foreign exchange earnings from tourism amounted to US\$ 3606.9 million in 2019. Therefore, it is impossible to underestimate tourism's importance and contribution to the development of Sri Lanka's economy. Developed economies can attract particularly business travellers, which enhances the foreign reserve of such countries. If Sri Lanka focuses its policy agenda towards attracting business travellers, a similar impact can be expected. As one of the famous tourist destinations in the south Asian region, Sri Lanka expanded its tourist industry for several decades, despite some significant disturbances in tourism. Therefore, it provides sufficient time to examine whether the development of the international tourism industry has significantly contributed to the country's economic development after introducing the economic reforms and new open economic policies in 1978. Since many developing economies are focusing on tourism as one of the growth determinants, Sri Lanka policymakers also paid attention to enhancing tourism as a growth engine. Currently, it is the third segment of the economy in terms of generating foreign earnings. Therefore, there has been an upsurge in interest in the role of tourism as a growth factor recently. Accordingly, the country's economic policies have frequently focused on promoting foreign tourism. However, understanding the mechanism behind the economic and tourism growth nexus is still vague. In such a context, it is an important research endeavour to investigate whether tourism can lead to economic growth. Its policy implications are also significant since tourism plays an important role in the Sri Lanka economy with multiplier effects.

Accordingly, the main objective of this study is to investigate whether and, if so, to what extent tourism growth responds to the 
development of the Sri Lanka economy during the period 1980-2019. A two-year grace period is allowed to implement the new economic policies introduced in 1978. The discourse of this investigation refers to the literature as the tourism-led growth hypothesis. The export-led growth hypothesis hypothesises that tourism would be the main determinant of overall long-run economic growth with many arguments. Such varied arguments will be discussed in the next study segment.

\section{Literature review}

The relationship between tourism development and economic growth has been a popular topic in the recent discourse of tourism literature (Kim \& Chen, 2006; Arslanturk, Balcilar, \& Ozdemir, 2011). There are three perspectives on the causal association between tourism and economic growth. The most discussed and emphasised perspective claims that tourism developments lead to economic growth. The extant literature refers to this perspective as the tourism-led growth (TLG) hypothesis (Lean \& Tang, 2009; Katircioglu, 2009; Akinboade \& Braimoh, 2010). The second perspective argues that economic development provides infrastructural development for the development of the tourism industry. The extant literature refers to this perspective as a growth-led tourism hypothesis (Jackman, 2012; Mishra \& Pradhan, 2019). Their argument emphasises twoway causation between tourism development and economic development. According to the extant literature, this perspective argues that there should be a bi-directional causality between tourism and economic growth (Corrie, Stoeckl, \& Chaiechi, 2013; Tugcu, 2014; Kumar, Loganathan, Patel, \& Kumar, 2015). The current study focuses on the first argument of the literature.

The contribution of tourism to economic growth has been confirmed in the literature with conflicting results (Corrie, Stoeckl, \& Chaiechi, 2013; Chou, 2013; Samimi, Sadeghi, \& Sadeghi, 2011; Lean \& Tang, 2009; Demiroz \& Ongan, 2005). Accordingly, many developing countries were able to upsurge government revenue significantly through the development of international tourism. In some cases, more than 50 per cent of government revenue has been generated by the tourism sector (Bird, 1991). Most of the available research in this area emphasises economic contribution to tourism growth, and these studies completely ignore the inefficiency involved in the tourism sector (Wicrmasinghe \& Ihalanayake, 2006).

In the case of the causal relationship between tourism and economic growth, a limited number of studies are available in the Sri Lankan context 
(Ranasinghe \& Deyshappriya, 2010; Wicrmasinghe \& Ihalanayake, 2006), while plenty of studies in other developing countries. Mishraet al. (2011), Samimiet al. (2011), Kreishan (2010) and Lee and Chang (2008) are some of the recent studies that investigate the relationship between tourism and economic growth.

Using cointegration and granger causality tests, Wickramasinghe and Ihalanayeka (2006) examined the causal nexus between Gross Domestic Product (GDP) and international tourist receipts in Sri Lanka. They have proven that a long-run equilibrium relationship between GDP and tourism receipt exists. The causal nexus is moving from tourism receipts to the GDP of Sri Lanka. The tourism significance in the Sri Lankan economy from 1970 to 2008 was considered by Ranasinghe and Deyshappriya (2011) in their study. The relationship between economic performance and tourism revenue was analysed using time series data, concluding that tourism plays an important role in economic development. However, this conclusion is suspicious because the major drawback of their study is that it has not utilised a comprehensive econometric approach such as Granger causality or cointegration despite the non-stationarity of time series data used.

Mishra et al. (2011) examined the dynamic relationship between tourism sector expansion and economic growth in India from 1978 to 2009 . Cointegration, error correction and granger causality tests were employed in their study for data analysis. Findings confirmed the tourism-led growth hypothesis maintained earlier for other countries that tourism has a positive impact on the economic activity and hence, the GDP growth of India for the long-run. Samimi et al. (2011) examined the causality and long-run relationships between economic growth and tourism development in 20 developing countries using Vector Autoregressive (VAR) approach for the period expanding from 1995 to 2009. Samimi et al. (2011) further reveal a bilateral causality and positive long-run relationship between those countries' economic growth and tourism development. There is evidence for developing countries to enhance the tourism sector through government involvement (Samimi et al., (2011); Mishra et al., 2011).

According to Kreishan (2010), a causal relationship exists between tourism earnings and Jordan's economic growth (GDP). The investigation is based on the annual time series data covering 1970 to 2009 . This study is also based on the two popular methods in the literature: Granger causality and Johansen's cointegration. Kreishan (2010) provides evidence for unidirectional causality, which runs from tourism to economic growth. Therefore, evidence from Jordan is consistent with Samimi et al. (2011) and Mishra et al. (2011) and confirms the tourism-led growth hypothesis; 
therefore, the focus on the operation of productive tourism-related policy strategies is confirmed.

According to the existing literature, different methodological approaches have been practised in investigating the causal nexus between tourism and economic growth. Lee and Chang (2008) are such an example. Lee and Chang (2008) employed a new heterogeneous panel cointegration technique. Their emphasis is different when compared to Samimi et al. (2011) and Mishra et al. (2011) in terms of techniques and geographical area (OECD and non-OECD countries), and focus. According to Lee and Chang (2008), economic growth has a greater impact when tourism receipts are considered, and the real impact varies for different countries. Their findings are vital. A unidirectional causal relationship between tourism developments to economic growth was investigated in OECD countries, whereas two-way causation was explored for non-OECD countries. Lee and Chang (2008) further reveal that the causal relationship is weak to some extent for Asia, and this conclusion generates controversial findings for Asia.

According to the discussion hitherto, the causal relationship between tourism and economic growth is ambiguous. It depends on different contexts and thus cannot reach a definite conclusion. Therefore, studying the causal relationships between tourism and economic growth in different frameworks is important. Consequently, it will be able to understand how different plans of action interact with the causality between tourism and economic growth and thereby implement respective policy recommendations for different contexts. Consequently, the current study aimed to reinvestigate the causality between tourism and economic growth for different time horizons using different econometric methodologies in the Sri Lankan context.

\section{Methods and materials}

This study employs several econometric methods to examine the relationship between GDP and Tourism Revenue (TR) from 1980-2019. Annual time series data were employed. The data sources were annual reports of the Central Bank of Sri Lanka (CBSL) and different issues of annual tourism statistics published by the Sri Lanka Tourism Development Authority (SLTDA). A logarithmic form of original data was employed since it provides some benefits for time series modelling. The empirical analysis is based on three variables, i.e., GDP, TR, and one period-lagged GDP $\left(G D P_{t-1}\right)$, assuming that the previous time's economic growth is pushing the next time's growth. The Engle-Granger two-step single equation error correction model was employed for the analysis since this study does not assume more than one cointegration relationship according to the nature 
of the data employed. The single equation model proposed by EngleGranger allows searching for short-term equilibrium relationships too. Therefore, the current study utilises the Engle-Granger single equation approach to investigate the long-run causality and short-run dynamics.

According to Phillips (1986), regression models that include nonstationary time series variables provide misleading results. Accordingly, the current study is conducted in three stages. The first stage determines the stationarity of variables using unit root tests. Cointegration tests are conducted in the second stage to investigate the long-run equilibrium relationships between variables. When two-time series variables move towards the same direction with comovements, these variables are jointly cointegrated (Gujarati, 2003, p.822). In the third step, the Granger causality among variables is investigated. If a one-time series variable provides statistically significant information to predict the future values of another time series, these time series are said to be a Granger cause (Granger, 1969).

The same order of integration among variables is a prerequisite for the long-run equilibrium relationship (Gujarati, 2003, p.805). Accordingly, tourism revenues (TR) and economic growth (GDP growth) must follow the same order of integration for the long-run equilibrium relationship between the two variables. This property of time series variables can be investigated with the help of different unit root tests. Both the Augmented Dickey-Fuller (ADF) and Phillips-Perron unit root tests are used to determine the stationarity of variables (Dickey \& Fuller, 1979). The following equations are estimated to achieve the needful. Since the random walk process may have different behaviours, several important decisions on the time series process are required. Consequently, it is assumed that the data-generating processes for this study follow a random walk process without drift, or it may have a drift, or it may have both deterministic and stochastic trends in the unit root testing process. Accordingly, three different forms of the unit root regressions are estimated to test three different null hypotheses.

When $Y_{t}$ follows a random walk process (no drift and no trend), and equation (1) is estimated.

$\Delta \mathrm{Y}_{\mathrm{t}}=\delta \mathrm{Y}_{\mathrm{t}-1}+\sum_{\mathrm{i}=1}^{\mathrm{m}} \alpha_{\mathrm{i}} \Delta \mathrm{Y}_{\mathrm{t}-\mathrm{i}}+\varepsilon_{\mathrm{t}}$

When just a random walk process follows $Y_{t}$ with a drift component, equation (2) is estimated.

$\Delta \mathrm{Y}_{\mathrm{t}}=\beta_{1}+\delta \mathrm{Y}_{\mathrm{t}-1}+\sum_{\mathrm{i}=1}^{\mathrm{m}} \alpha_{\mathrm{i}} \Delta \mathrm{Y}_{\mathrm{t}-\mathrm{i}}+\varepsilon_{\mathrm{t}}$ 
When $Y_{t}$ is followed by just a random walk process with a drift around the deterministic trend component, and equation (3) is estimated.

$\Delta \mathrm{Y}_{\mathrm{t}}=\beta_{1}+\beta_{2} \mathrm{t}+\delta \mathrm{Y}_{\mathrm{t}-1}+\sum_{\mathrm{i}=1}^{\mathrm{m}} \alpha_{\mathrm{i}} \Delta \mathrm{Y}_{\mathrm{t}-\mathrm{i}}+\varepsilon_{\mathrm{t}}$

The three different null hypotheses are tested traditionally as onesided tests. The null hypotheses involve the testing for $\delta=0$ versus the alternative hypothesis $\delta<0$. Therefore, more negativity of the test statistic aids the rejection of the null hypothesis in practice. If the null hypothesis is rejected under any condition, subsequent differences in variables should be obtained until achieving stationarity. If the null hypothesis does not reject at the fit stage, variables can be used in their level forms.

This study also utilises the Phillips-Perron (PP) test to analyse the unit root properties of variables (Phillips \& Perron, 1988). The PP test is more robust than the ADF test in the presence of autocorrelation and heteroscedasticity among variables. PP test uses Newey-West's (1987) heteroscedasticity and autocorrelation consistent covariance matrix estimator in testing the unit roots. Under the null hypothesis, the PP test follows the same asymptotic distributions as the ADF tau statistic. Researchers do not want to specify a lag length for the test regression. PP test estimates the regression equation (4).

$\mathrm{Y}_{\mathrm{t}}=\beta_{1}+\delta \mathrm{Y}_{\mathrm{t}-1}+\varepsilon_{\mathrm{t}}$

$\mathrm{H}_{0}: \delta=1$ and $\mathrm{H}_{1}: \delta<1$ are the respective null and alternative hypotheses, and these hypotheses are tested based on a nonparametric estimation procedure.

After determining the order of integration of the variables, the residual-based Engle-Granger cointegration approach is used to investigate the long-run equilibrium relationship between GDP and TR. The problem of formally testing for cointegration in a bivariate system was analysed in detail by Engle and Granger (1987). Engle and Granger suggested a simple two-step approach to the problem and the cointegration test aimed at determining whether single-equation estimates of the equilibrium error appeared to be stationary. In order to analyse a cointegration relationship between GDP and TR, the cointegration equation (5) was estimated:

$\operatorname{lnGDP} P_{t}=\alpha+\beta_{1} \operatorname{lnTR}+\beta_{2} \operatorname{lnGDP}_{\mathrm{t}-1}+\varepsilon_{\mathrm{t}}$

Stock (1987) has shown that the estimators $\widehat{\alpha}$ and $\widehat{\beta}$ in equation (5) 
are super consistent. Equation (5) can be estimated using different methods as in the literature. The current study proposes three different approaches, namely; 1) fully modified ordinary least squares (FMOLS) estimation proposed by Phillips and Hansen (1990), 2) canonical cointegration regression (CCR) estimation proposed by Park (1992), and 3) dynamic ordinary least squares (DOLS) estimation proposed by Saikkonen (1992) and Stock and Watson (1993).

In any of the suggested approaches, when the residuals of cointegration equations (5) are stationary, the variables in the equation are considered cointegrated. In other words, stationary residuals in equation (5) imply that the two variables, GDP and TR, follow a long-run equilibrium relationship (Brooks, 2008).

\section{Empirical analysis and discussions}

This study was entirely based on secondary data, i.e., time-series data obtained from the annual reports of SLTDA and CBSL. Since the study utilises annual time series data, it is worthwhile to plot the time series to detect the time-series properties of variables. The main two variables, GDP and TR, employed for the analysis are frequently hindered by inflation and thus probably depict different oscillations in the time-series plot. Therefore, the two variables were measured in millions of US dollars.

Figure 1. represents the time series plot of GDP and TR for the sample period, and the visual impression of the time series plot confirms that there are comovements between GDP and TR. Over the full-time span, both variables depict a similar movement. Even though it has observed a slight deviation of the motion path of the two variables in recent years, the two-time series maintained the particular comovements. The tourism industry and economic growth of Sri Lanka have steepened after 2009 as a result of the end of the ethnic war in 2009. 
Nisantha, K., \& Erandathie, L.

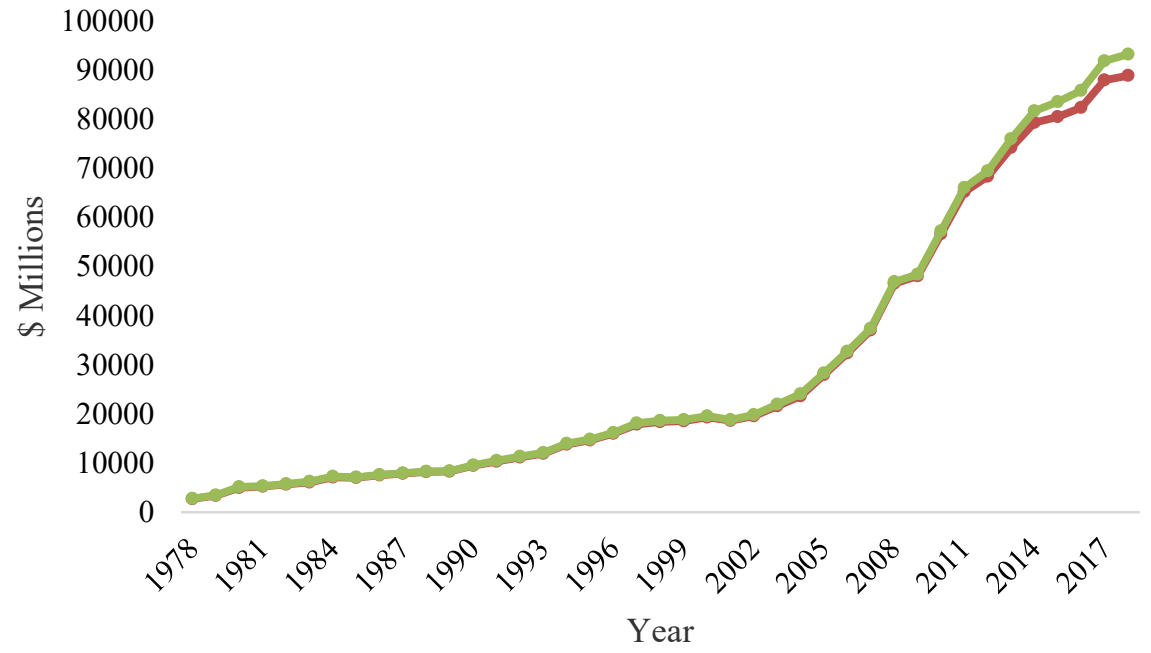

$\longrightarrow \mathrm{GDP}=\mathrm{TR}$

Figure 1. Time series plot of GDP and tourism revenue 1978 - 2018 (Rs. Million)

Therefore, Figure 1; provides adequate evidence to continue the empirical analysis towards cointegration analysis. As the first stage of the empirical analysis, it is required to determine the order of integration of the time series variables since the non-stationary variables may produce spurious results. Therefore, the analysis technically conducts the unit root test of ADF and PP tests for the variables. The logarithms of variables are employed for the analysis since logarithmic values remove the unwanted oscillations of time series, and estimates can be interpreted as elasticity values.

\subsection{Results of unit root tests}

Table 1. Results of ADF unit root test

\begin{tabular}{lllllll}
\hline \multirow{2}{*}{ Variable } & $\begin{array}{l}\text { Constant } \\
\text { Level }\end{array}$ & $\begin{array}{l}\text { First - } \\
\text { Difference }\end{array}$ & Conclusion & Level & First -Difference & Conclusion \\
\hline $\operatorname{lnGDP}$ & -0.53784 & $-4.87629^{* *}$ & $\mathrm{I}(1)$ & -1.91998 & $-4.83128^{* *}$ & $\mathrm{I}(1)$ \\
& & & & & & \\
$\operatorname{lnTR}$ & -2.23046 & $-4.23559^{* *}$ & $\mathrm{I}(1)$ & -2.04827 & $-4.54294^{* *}$ & $\mathrm{I}(1)$ \\
\hline
\end{tabular}

$* *$ and $*$ denote the statistical significance of the unit root hypothesis under Mackinnon critical values at $1 \%$ and $5 \%$ respectively.

Tables 1 and 2 present the results of the unit tests of ADF and PP tests, respectively. Unit root testing has been done at the level from 
variables and for their first differences. Further, unit roots run under the conditions of assuming a constant and a trend. The results of unit root tests (in level) indicate that the null hypothesis of the unit root cannot be rejected at 1 per cent and 5 per cent levels of significance for both types of tests. However, the null hypothesis of unit root is rejected at 1 per cent and 5 per cent levels of significance when the test is run on the first differences of respective variables. This suggests that the data are initially stationary (or integrated) but not in level form.

Table 2. Results of Phillip-Perron unit root test

\begin{tabular}{lllllll}
\hline \multirow{2}{*}{ Variable } & Constant & & \multicolumn{4}{l}{ With trend } \\
& Level & First -difference & Conclusion & Level & First -difference & Conclusion \\
\hline lnGDP & -0.20071 & $-4.89261^{* *}$ & $\mathrm{I}(1)$ & -1.80970 & $-4.78947^{* *}$ & $\mathrm{I}(1)$ \\
$\operatorname{lnGDP}$ & -0.20011 & $-4.58712^{* *}$ & $\mathrm{I}(1)$ & -1.79078 & $-4.47713^{* *}$ & $\mathrm{I}(1)$ \\
$\operatorname{lnTR}$ & -2.13374 & $-4.24239^{* *}$ & $\mathrm{I}(1)$ & -2.01159 & $-4.55437^{* *}$ & $\mathrm{I}(1)$ \\
\hline ** and * denote rejection of a unit root null hypothesis based on Mackinnon critical values at $1 \%$ and \\
$5 \%$ respectively.
\end{tabular}

\subsection{Results of the cointegration test}

When all the time series variables follow the same order of integration, a single equation cointegration test proposed by Engle and Granger (1987) can be performed to investigate the long-run equilibrium inherited among variables. Accordingly, the estimation procedure proposed by Engle and Granger (1987) was employed on international tourism receipts (TR) and real GDP and lagged values of the real GDP in Sri Lanka. The empirical results of the single-equation cointegration models are summarised in Table 3. Findings revealed that GDP and TR are cointegrated under (with constant) and (with constant and trend) situations.

Table 3. Results of cointegration Tests

\begin{tabular}{lllll}
\hline Variable & $\begin{array}{l}\text { With constant } \\
\text { tau-statistic }\end{array}$ & Z-statistic & \multicolumn{2}{c}{ With a constant and trend } \\
& -4.52412 & -68.56140 & -4.73885 & z-statistic \\
\hline \multirow{2}{*}{ LGDP $_{\mathrm{t}}$} & $(0.0041)$ & $(0.0000)$ & $(0.0097)$ & -77.60723 \\
& -3.41301 & -57.49030 & -3.62663 & $(0.0000)$ \\
LGDP $_{\mathrm{t}-1}$ & $(0.0030)$ & $(0.0000)$ & $(0.0071)$ & -56.60203 \\
\multirow{2}{*}{$\mathrm{LTR}$} & -4.04747 & -42.88294 & -4.53267 & $(0.0000)$ \\
& $(0.0138)$ & $(0.0000)$ & $(0.0159)$ & -57.70507 \\
\hline
\end{tabular}

Table 4. reports the results of the econometric estimation of long-run relationships between real GDP, GDP $\mathrm{t}_{\mathrm{t}-1}$ and TR. These estimates were obtained through different estimation procedures, namely, Fully Modified Least Squares (FMOLS), Canonical Cointegrating Regression (CCR) and 
Nisantha, K., \& Erandathie, L.
Long-Run Nexus of Tourism and Economic Growth in Sri Lanka: Empirical Evidence Using Cointegration

Analysis

Dynamic Least Squares (DOLS), where these methods were proposed to correct the biased estimation of cointegration relationship using OLS in single-equation contexts as noted earlier. FMOLS and CCR estimates provide similar results when slightly different results are given in the DOLS estimates. Findings reveal that tourism revenue contributes around 9 per cent to economic growth in Sri Lanka over the period from 1980 to 2019. Further, it reveals that previous growth controls the current growth by approximately 20 per cent.

Table 4. Results of the long-run relationship between GDP and TR

\begin{tabular}{lllll}
\hline Dependent variable: LGDP & & & & \\
Estimation method & Coefficient & Estimate & S.E. & P-value \\
\hline \multirow{2}{*}{$\begin{array}{l}\text { Fully modified least squares } \\
\text { (FMOLS) }\end{array}$} & LTR & 0.092065 & 0.024463 & 0.0006 \\
& LGDP $_{\text {t- }}$ & 0.220144 & 0.001121 & 0.0000 \\
Canonical cointegrating regression & Constant & 8.306651 & 0.006870 & 0.0000 \\
(CCR) & LTR & 0.094965 & 0.021765 & 0.0000 \\
& LGDP $_{\text {t-1 }}$ & 0.213304 & 0.003343 & 0.0002 \\
& Constant & 8.811236 & 0.011410 & 0.0000 \\
Dynamic least squares (DOLS) & LTR & 0.144869 & 0.026633 & 0.0003 \\
& LGDP $_{\text {t-1 }}$ & 0.201123 & 0.022456 & 0.0005 \\
& Constant & 8.660293 & 0.100023 & 0.0011 \\
\hline
\end{tabular}

\subsection{Results of parsimonious error correction model}

In the previous section, it was revealed that there is a long-run relationship between tourism revenue and economic growth in Sri Lanka. In the short run, there may be deviations from this equilibrium, and it needs to confirm whether such disequilibrium converges to the long-run equilibrium. Error correction mechanism (ECM) can produce precise short-run dynamics and provides the rate of convergence (correction of the disequilibrium per time unit) to equilibrium. Consequently, the error correction mechanism reconciles the short-run and long-run behaviour. The optimal lag length is required to obtain an accurate and valid estimation of the error correction model. The system's optimal lag length was 1 , determined according to the Schwarz Information Criterion (SIC). The empirical results of the estimation of the error correction model are reported in Table 5. The model coefficients and their respective p-values are presented.

The empirical results confirm the statistical significance and the negativity of the error-correction term (EC) at the 1 per cent level of significance $(p<0.01)$. The estimated coefficient $(-0.0479)$ shows the rate of convergence to the equilibrium in the short run. Precisely, the speed of adjustment of any disequilibrium towards a long-run equilibrium is about 4.8 per cent. Therefore, the disequilibrium in real GDP is corrected by 4.5 
per cent per year.

Table 5. Error correction estimates (OLS): Short-run dynamics

\begin{tabular}{lll}
\hline Error correction model & Coefficient & P-value \\
\hline Constant & 0.0979 & 0.0018 \\
$\Delta \ln T R$ & 0.0600 & 0.0613 \\
$\Delta \operatorname{lnGDP}_{\mathrm{t}-1}$ & 0.0955 & 0.0069 \\
$\mathrm{EC}$ & -0.0479 & 0.0008 \\
\hline
\end{tabular}

$\begin{array}{ll}\text { Adjusted } \mathrm{R}^{2}\left(\overline{\mathrm{R}}^{2}\right) & 0.4243 \\ \text { Durbin-Watson statistic (DW) } & 1.8534 \\ \text { Standard error of residuals } \quad 0.0361 & \end{array}$

\begin{tabular}{lll}
\hline $\begin{array}{l}\text { Diagnostic tests } \\
\text { Type of the test statistic }\end{array}$ & Value & P-value \\
\hline $\begin{array}{l}\text { Normality: Chi square } \chi^{2}(3) \\
\begin{array}{l}\text { Heteroscedasticity } \\
\text { LM test }\left(\mathrm{TR}^{2}\right)\end{array}\end{array}$ & 1.0250 & 0.2048 \\
$\begin{array}{l}\text { Stability of parameters } \\
\text { RESET }\end{array}$ & 5.4450 & 0.8580 \\
squares and cubes & & \\
$\mathrm{F}(3,37)$ & & \\
squares only & 0.8368 & 0.5176 \\
$\mathrm{~F}(2,38)$ & 1.5176 & 0.7678 \\
cubes only & & \\
$\mathrm{F}(2,38)$ & 1.5035 & 0.7647 \\
Serial correlation & & \\
LM F(2,38) & 1.0157 & 0.6282 \\
\hline
\end{tabular}

All values in Table 5. are reported after rounding off to four decimal places. The normality of residuals is accepted at the 5 per cent level of significance since it does not reject the null hypothesis of normality $\left(\chi_{(3)}^{2}=\right.$ $1.025, p=0.2048>0.05)$ and this significant result warrants that the most important assumption of the model is satisfied. The model is also free from the heteroscedasticity problem since the null hypothesis of no heteroscedasticity in the model is accepted under a 5 per cent level of significance $(p=0.8580>0.05)$. It is necessary to test the model residuals for serial correlation for its validity. LM test provides the standard way of investigating the serial correlation among residuals. According to the empirical results, the null hypothesis of no serial correlation among residuals does not reject at the 5 per cent level $(\mathrm{p}=0.6282>0.05)$. This conclusion is consistent with the Durbin-Watson test $(\mathrm{DW}=1.8534)$ and implies no first-order positive serial correlation among residuals. This empirical investigation employed Ramsey's RESET test for model specification errors. The test reveals that there is not any form of misspecification by rejecting the null hypothesis of no misspecification 
errors in the model at any traditional levels of significance $(p>0.0000)$. Accordingly, the validity of the estimated model is confirmed.

\subsection{Results from Granger causality tests}

Granger (1988) stated that if there is a cointegration relationship between two variables, the Granger causality operates at least in one direction. It is also pointed out that negative and statistically significant error correction term implies a long-run causality between the variables considered. Table 6. provides a statistical investigation of the causal nexus between LGDP and LTR in Sri Lanka. Two hypotheses were tested to detect the Granger causality based solely on the theoretically accepted F test. F test requires optimal lag lengths based on the smallest Akaike Information Criteria (AIC) values. The empirical findings in Table 6. provide evidence for a one-way causal relationship and moves from tourism to economic growth. Accordingly, the development of tourism in terms of its revenue is one of the important determinants of economic growth in Sri Lanka.

Table 6. Granger causality test

\begin{tabular}{llll}
\hline Null hypothesis & F-statistic & P-value & Conclusion \\
\hline LGDP does not Granger cause LTR & 1.23255 & 0.3135 & Does not have the Null \\
LTR does not Granger cause LGDP & 3.43668 & 0.0280 & $\begin{array}{l}\text { Hypothesis. } \\
\text { Reject the null hypothesis. }\end{array}$ \\
\hline
\end{tabular}

\section{Conclusion}

It is a fundamental question for policymakers whether international tourism can lead to economic growth for many developing economies because policymakers of such economies are struggling to decide how to invest public revenue in terms of the long-run economic livelihood of citizens. Tourism is one such alternative. The extant literature on tourism has significantly proven a positive relationship between international tourism and economic growth. Many of the studies of tourism and growth have combined into the tourism-led growth hypothesis, which was tested by tourism researchers using different econometric modelling approaches.

The current tourism research frequently employs the tourism-led growth hypothesis to investigate the growth mechanism underlying the positive association between economic growth and tourism. Accordingly, this study investigates the nexus between real economic growth in terms of real GDP and real tourism earnings from tourism in Sri Lanka, applying the single equation cointegration analysis proposed by Engle and Granger. The 
results revealed a cointegration relationship between economic growth and tourism. Therefore, the growth mechanism discovered a long-run equilibrium relationship though there is a disequilibrium in the short run. Accordingly, the findings of this study confirm the tourism-led growth hypothesis of the Sri Lankan economy, which has been maintained earlier for other developing countries. These findings are consistent with Wicramasinghe and Ihalanayake (2006) though they have employed an entirely different technique and a different time horizon for their study. Therefore, the empirical findings reveal that the correlation between tourism and economic growth is further continuing in the Sri Lankan economy. Findings further emphasise the necessity of long-term strategies that relate to the bidirectional development between tourism and the economy in Sri Lanka. Therefore, government involvement is a must for developing productive tourism development strategies to increase visitor arrivals and visitor expenditures during their stay in Sri Lanka to benefit its economy to a greater extent.

Even though the government implies that there are many activities initiated to develop international tourism-related activities, empirical evidence of this study rejects the economic-driven tourism-growth hypothesis. This raises the question of whether tourism has grown in line with Sri Lanka's economic growth. According to the report of the Tourist Board and the Central Bank, a huge amount of money is invested annually for the advancement of the tourism industry. The question then arises as to why this is not shown in an empirical study. There are two possible reasons. First, is the tourism industry's budget being spent on it? Second, whether the expenditures incurred by the tourism industry utilised efficiently? This is an important future research issue emanating from the findings of this study. Therefore, in a future investigation, one can address the efficiency of the Sri Lankan tourism industry in terms of inputs and outputs and economies of scale.

The findings of the study provide several policy conclusions. Although Sri Lanka has limited resources for its development process, the investment in the tourism industry is huge. Therefore, there is no need for further investment and what is needed is the implementation of policies to increase the number of tourists arriving and their stay in the country. Although the 30-year-long ethnic war in Sri Lanka is over, the occasional terrorist turns to ensure that Sri Lanka is not a safe destination. Therefore, Strategic planning is necessary to safeguard Sri Lanka as one of the safest destinations in the world for tourists. The tourism sector and the Sri Lankan government must collectively implement a cooperative sustainable tourism 
strategic plan.

\section{Declaration of conflicting interests}

The author(s) declared no potential conflicts of interest with respect to the research, authorship, and/or publication of this article

\section{References}

Akinboade, O., \& Braimoh, L. A. (2010). International tourism and economic development in South Africa: A Granger causality test. International Journal of Tourism Research, 12, 149-163. https://doi.org/10.1002/jtr.743

Arslanturk, Y., Balcilar, M., \& Ozdemir, Z. A. (2011). Time-varying linkages between tourism receipts and economic growth in a small open economy. Economic Modelling, 28(1-2), 664-671. https://doi.org/10.1016/j.econmod.2010.06.003

Asian Development Bank. (2011). Asian development outlook: Update 2011. Philippines: Asian Development Bank. https://doi.org/10.22617/fls200256-3

Bianchi, R. V., \& Man, F. d. (2020). Tourism, inclusive growth and decent work: A political economy critique. Journal of Sustainable Tourism, 29(1), 1-19. https://doi.org/10.1080/09669582.2020.1730862

Bird, R. M. (1992). Taxing Tourism in Developing Countries. World Development, 20, 1145-1158. https://doi.org/10.1016/0305750x(92)90006-h

Brooks, C. (2008). Introductory Econometrics for Finance (2nd ed.). New York: Cambridge University Press.

Central Bank of Sri Lanka. (1980-2019). .Annual reports. Colombo: CBSL.

Chou, M. C. (2013). Does tourism development promote economic growth in transition countries? A panel data analysis. Economic Modelling, 33, 226-232. https://doi.org/10.1016/j.econmod.2013.04.024

Corrie, K., Stoeckl, N., \& Chaiechi, T. (2013). Tourism and economic growth in Australia: An empirical investigation of causal links. Tourism Economics, 19(6), 1317-1344. https://doi.org/10.5367/te.2013.0241

Demiroz, D. M., \& Ongan, S. (2005). The contribution of tourism to the long-run Turkish economic growth. Journal of Economics, 9(53), 880-894.

Dickey, D., \& Fuller, W. (1979). Distribution of the estimators for autoregressive time series with a unit root. Journal of the American 
Management \& Economics Research Journal $\mid$ Vol. 3 No. 1 (2021) pp. $25-43$

Statistical Association, $\quad 74, \quad 427-431$. https://doi.org/10.1080/01621459.1979.10482531

Du, D., Ng, P., \& Lew, A. A. (2016). Tourism and economic growth. Journal of Travel Research, 55(4), 454-464.

Engle, R., \& Granger, C. W. (1987). Co-integration and error correction: Representation, estimation and testing. Econometrica, 55(2), 251276. https://doi.org/10.2307/1913236

Granger, C. W. (1988). Some recent development in a concept of causality. Journal of Econometrics, 39, 199-211. https://doi.org/10.1016/03044076(88)90045-0

Gujarati, D. N. (2005). Basic Econometrics (4th ed.). Singapore: The McGraw-Hill.

Jackman, M. (2012). Revisiting the tourism led growth hypothesis for Barbados: A disaggregated Market approach. Regional and Sectoral Economic Studies, 12(2), 15-26.

Katircioglu, S. (2009). Revising the tourism-led-growth hypothesis for Turkey using the bounds test and Johansen approach for cointegration. Tourism Management, 30, 17-20. https://doi.org/10.1016/j.tourman.2008.04.004

Kim, H. J., \& Chen, M. H. (2006). Tourism expansion and economic development: The case of Taiwan. Tourism Management, 27(5), 925-933. https://doi.org/10.1016/j.tourman.2005.05.011

Kreishan, F. M. (2010). Tourism and Economic Growth: The Case of Jordan. European Journal of Social Sciences, 15(2), 229-234.

Kumar, R. R., Loganathan, N., Patel, A., \& Kumar, R. D. (2015). Nexus between tourism earnings and economic growth: A study of Malaysia. Quality \& Quantity, 49(3), 1101-1120. https://doi.org/10.1007/s11135-014-0037-4

Lean, H. H., \& Tang, C. F. (2009). Is the tourism-led growth hypothesis stable for Malaysia? A note. International Journal of Tourism Research, 12(4), 375-378. https://doi.org/10.1002/jtr.759

Lee, C. C., \& Chang, C. P. (2008). Tourism development and economic growth: A closer look at panels. Tourism Management, 29, 180-192. https://doi.org/10.1016/j.tourman.2007.02.013

Mishra, P. K., Rout, H. B., \& Mohapatra, S. S. (2011). Causality between Tourism and Economic Growth: Empirical Evidence from India. European Journal of Social Sciences, 18(4), 518-527.

Mishra, P., \& Pradhan, B. (2019). Empirics of tourism-led growth in India, 1995 to 2016. Journal of Environmental Management and Tourism, 9(6), 1190-1201. https://doi.org/10.14505//jemt.v9.6(30).08 
Newey, W. K., \& West, K. D. (1987). A simple positive semidefinite, heteroscedasticity consistent covariance matrix. Econometrica, 55, 703-708. https://doi.org/10.2307/1913610

Park, Y. J. (1992). Canonical cointegrating regression. Econometrica, 60, 119-143.

Phillips, C. B. (1986). Understanding spurious regressions in econometrics. Journal of Econometrics, 33, 311-340. https://doi.org/10.1016/03044076(86)90001-1

Phillips, C. B. (1988). Testing for a unit root in time series regression. Biometrica, 75(3), 335-346.

Phillips, C. B., \& Hansen, B. E. (1990). Statistical interference in instrumental variable regression with I (1) process. Review of Economic Studies, 57, 99-125.

Ranasinghe, R., \& Deyshappriya, R. (2010). Analysing the significance of tourism on Sri Lankan economy: An econometric analysis. Conference proceedings (pp. 1-19). Kelaniya: University of Kelaniya.

Saikkonen, P. (1992). Estimation and testing of cointegrated system by an autoregressive approximation. Econometric Theory, 8, 1-27. https://doi.org/10.1017/s0266466600010720

Samimi, A. J., Sadeghi, S., \& Sadeghi, S. (2011). Tourism and Economic Growth in Developing Countries: P-VAR Approach. Middle-East Journal of Scientific Research, 10(1), 28-32.

Sri Lanka Tourism Development Authority. (2019). Annual Tourism Statistics (different issues). Colombo: SLTDA.

Stock, J. H. (1987). Asymptotic properties of least square estimators of cointergrating vectors. Econometrica, 55, 1035-1056. https://doi.org/10.2307/1911260

Stock, J. H., \& Watson, M. (1993). A simple estimation of cointegrating vectors in higher order integrated system. Econometrica, 61, 873820. https://doi.org/10.2307/2951763

Tse, R. Y. (2001). Estimating the impact of economic factors on tourism: evidence from Hong Kong. Tourism Economics, 7(3), 277-293. https://doi.org/10.5367/000000001101297874

Tugcu, C. T. (2014). Tourism and economic growth nexus revisited: A panel causality analysis for the case of the Mediterranean Region. Tourism Management, 207-212. https://doi.org/10.1016/j.tourman.2013.12.007

Wanhill, S. R. (1994). Evaluating the worth of investment incentives for tourism development. Journal of Travel Research, 33(2), 33-39. 
\begin{tabular}{l|l|l} 
Management \& Economics Research Journal & Vol. 3 No. 1 (2021) & pp. 25-43
\end{tabular}

https://doi.org/10.1177/004728759403300206

Wickremasinghe, G. B., \& Ihalanayake, R. (2006, December 10). The causal relationship between tourism and economic growth in Sri Lanka: some empirical evidence. 1-17. Victoria University. 